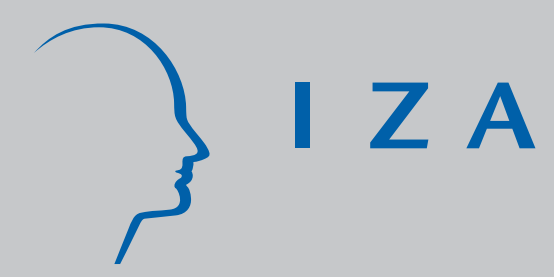

IZA DP No. 3950

Ethnicity and the Immigration of Highly Skilled Workers to the United States

Guillermina J asso

J anuary 2009 


\title{
Ethnicity and the Immigration of Highly Skilled Workers to the United States
}

\author{
Guillermina Jasso \\ New York University \\ and IZA
}

Discussion Paper No. 3950

January 2009

IZA
P.O. Box 7240
53072 Bonn
Germany

Phone: +49-228-3894-0

Fax: +49-228-3894-180

E-mail: iza@iza.org

Any opinions expressed here are those of the author(s) and not those of IZA. Research published in this series may include views on policy, but the institute itself takes no institutional policy positions.

The Institute for the Study of Labor (IZA) in Bonn is a local and virtual international research center and a place of communication between science, politics and business. IZA is an independent nonprofit organization supported by Deutsche Post World Net. The center is associated with the University of Bonn and offers a stimulating research environment through its international network, workshops and conferences, data service, project support, research visits and doctoral program. IZA engages in (i) original and internationally competitive research in all fields of labor economics, (ii) development of policy concepts, and (iii) dissemination of research results and concepts to the interested public.

IZA Discussion Papers often represent preliminary work and are circulated to encourage discussion. Citation of such a paper should account for its provisional character. A revised version may be available directly from the author. 


\section{ABSTRACT \\ Ethnicity and the Immigration of Highly Skilled Workers to the United States}

This paper examines ethnicity among highly skilled immigrants to the United States. The paper focuses on five classic components of ethnicity - country of birth, race, skin color, language, and religion - among persons admitted to legal permanent residence in the United States in 2003 in the three main employment categories (EB-1, EB-2, and EB-3), using data collected in the U.S. New Immigrant Survey. Initial findings include: (1) The visa categories have distinctive ethnic configurations. India dominates EB-2 and European countries EB-1. (2) The ethnicity portfolio contains more languages than religions. (3) Language is shed before religion, and religion may not be shed at all, except among the ultra highly skilled of EB-1. (4) Highly skilled immigrants are mostly male; they are not immune from lapsing into illegality; they have a shorter visa process than their cohortmates; smaller proportions than in the cohort overall intend to remain in the United States. (5) Larger proportions in EB-2 and EB-3 sent remittances than in the cohort overall. (6) A little measure of assimilation - using dollars to describe earnings in the country of last residence, even when requested to use the country's currency - suggests that highly skilled immigrants are more likely to "think in dollars" than their cohortmates. Further work is taking a deeper look at these patterns in a multivariate context, attentive to selectivity processes and the Globalista impulse.

JEL Classification: F22, F24, J15, J24, J61, J68, K42, O15

Keywords: immigration policy, immigrant selection criteria, employment immigration, highly skilled immigration, illegal immigration, ethnicity, race, language, religion, remittances, assimilation, globalization

Corresponding author:

Guillermina Jasso

Department of Sociology

New York University

295 Lafayette Street, $4^{\text {th }}$ Floor

New York, NY 10012-9605

USA

E-mail: gj1@nyu.edu

\footnotetext{
* The New Immigrant Survey project is supported by the U.S. National Institutes of Health (NICHD and NIA) under grant HD33843, with partial support from the U.S. National Science Foundation, the U.S. Citizenship and Immigration Services, and the Pew Charitable Trusts. Earlier versions of portions of this paper were presented at the NIS Conference, Vanderbilt University, March 2008, and at the $20^{\text {th }}$ Annual Group Processes Conference, Boston, MA, July 2008. I am grateful to participants at those meetings and other colleagues for many valuable comments and suggestions, especially Monica Espinoza Higgins, Michael Hoefer, Jennifer Martin, and Vivek Wadhwa; and I thank the anonymous referees and the editors for their close reading and valuable comments. Intellectual and financial support from New York University is also gratefully acknowledged. This paper is forthcoming in International Journal of Manpower.
} 


\section{INTRODUCTION}

As with so much in life, there are two types of ethnicity - the ethnicity we are born to and the ethnicity we choose. Immigration provides a splendid laboratory for observing ethnicity and its operation and change, for migrants can alter, or add to, the ethnicity portfolio (Constant and Zimmermann 2008).

Meanwhile, highly skilled migrants command attention, as countries around the world compete for talent, the skilled find expanding opportunities to use their talents, and concerns arise about the implications for source countries (Docquier and Schiff 2008; Niimi, Ozden, and Schiff 2008). And highly skilled migrants, who may identify more with their profession than with their ascribed characteristics, may more transparently display the operation of ethnicity.

This article reports a first reconnaissance over ethnicity among highly skilled immigrants to the United States. We examine five classic components of ethnicity - country of birth, race, skin color, language, and religion - in the New Immigrant Survey (NIS) cohort of persons who obtained U.S. legal permanent residence in 2003 , focusing on principals in the three main visa categories for highly skilled immigrants. We assess in a preliminary way change in the two malleable components - language and religion -- from childhood to adulthood, and lay the groundwork for exploring the effects of ethnicity on assimilation, globalism, and other important outcomes. Of course, interpreting the effects of ethnicity will be daunting, as ethnicity operates both directly through the immigrant and also indirectly, as nonmigrants in both origin and destination country may shape the social, economic, and legal climate in ethnic-specific ways, generating immigrant reactions to the ethnic-specific environments they face.

\section{THEORETICAL AND EMPIRICAL FRAMEWORK}

\subsection{Highly Skilled Immigrants to the United States}

This article focuses on immigrants who gain legal permanent residence (LPR) as principals in the employment preference categories specifically designed to attract highly skilled immigrants. These are the first three employment preference categories, minus the less-skilled 
"other workers" of the third category. ${ }^{1}$

The United States currently admits about a million persons a year to LPR. Excluding IRCA legalizations, annual totals/averages were 781,848 in 1991-1995 and 771,307 in 1996-2000, increasing to 980,344 in 2001-2005, 1,266,047 in 2006, and 1,052,322 in 2007.

LPR visas are of two main types, numerically unlimited and numerically limited.

Numerically unlimited visas are granted to the spouses, minor children, and parents of adult U.S. citizens (a set collectively called "immediate relatives of U.S. citizens"). Almost half of all visas go to this group, with spouses of U.S. citizens by far the largest subset - e.g., 339,843 in 2006 and 274,358 in 2007.

Numerically limited visas are granted to three main categories of immigrants: (1) other family immigrants; (2) employment immigrants; and (3) diversity immigrants (winners of the lottery visas designated for persons from countries underrepresented in recent immigration).

Two additional categories include subsets of both numerically limited and unlimited visas. These are (4) humanitarian immigrants (including refugees, asylees, and parolees) and (5) legalization immigrants, that is, illegal immigrants who are becoming legal, including registryprovision immigrants and cancellation-of-removal immigrants, plus beneficiaries of special legalization legislation (Jasso et al. 2008). ${ }^{2}$

The LPR visas of interest here are: EB-1 for priority workers; EB-2 for professionals with advanced degrees or persons of exceptional ability; and EB-3 for skilled workers and professionals (and a subset we exclude from consideration comprised of less-skilled "other workers"). The number of visas available each year in these categories, for both principal and family members, is 120,120 , plus additional visas if usage is low in the fourth and fifth

1 Of course, highly skilled immigrants are also found in other categories, for example, as spouses of U.S. citizens or refugees.

2 Other foreign-born in the United States include "nonimmigrants" (who have legal temporary documents) and illegal immigrants, the latter an obvious reflection of the gap between the desire to immigrate and the supply of visas. 
employment categories and/or in the family preferences, minus 5,000 visas for "other workers" for a total of at least 115,120 and higher in some years (e.g., 121,253 in 2007). Table 1 provides a brief description of the three employment categories. ${ }^{3}$

- Table 1 about here -

The process of obtaining an employment visa has several steps and involves not only the prospective immigrant but also the employer (i.e., the sponsor) and three government agencies the Department of Labor, the Department of State, and the Department of Homeland Security (chiefly via Citizenship and Immigration Services). For description of the process - the pertinent applications and requirements, the priority date for establishing position in the queue, and waiting times - see Wadhwa et al. (2007).

Recently Wadhwa et al. (2007) estimated the number of principals waiting in the U.S. for employment-based LPR visas as of late 2006 at half a million, with another half a million family members; the corresponding worldwide total was 1.2 million.

\subsection{Ethnicity}

We examine five classic components of ethnicity: country of birth, race, skin color, language, and religion. The groundbreaking Executive Order 10925 issued by President John F. Kennedy on 6 March 1961 prohibited discrimination on the basis of "race, creed, color, or national origin" -- significantly, all but language.

The five components differ in the possibility for alteration. One can never change the things of the past, and thus cannot change country of birth, childhood language, or childhood religion. And one cannot easily change skin color or other physical attributes such as those associated with race. Both language and religion, however, can be changed. Throughout history we observe language adoption - sometimes spectacularly, as in the case of Joseph Conrad, who

3 The fourth and fifth employment categories are less central here, and small. The fourth includes a mix of "special immigrants" such as ministers and juvenile court dependents, and the fifth is for investors. In FY 2007, of the 72,867 employment principals, only $4.2 \%$ were in these categories. 
came to English (his third language) in adulthood - and of course religion adoption.

The five components also differ in their visibility. Race and skin color are visible, but origin country and religion are not necessarily visible, and language is heard not seen. Of course, it may be possible to discern language and religion in a person's proper name, which may be "read" and thus "visible".

Finally, ethnicity, via its components, may have an associated Zeitgeist, and this Zeitgeist may shape personal behavior and decisionmaking. But ethnicity may also arouse reactions in others, which then alter the environment faced by the immigrant. For this reason, it may be difficult to unambiguously interpret behaviors associated with ethnicity.

\subsection{New Immigrant Survey Data}

Data are drawn from the NIS 2003 cohort. The sampling frame consists of all new LPRs whose records were compiled in the 7-month period May-November 2003. On average, interviews were conducted approximately four months after admission to LPR; mean (median) time elapsed between LPR and interview was 17 (14) weeks. All respondents were interviewed in the language of their choice -- a total of 95 languages. The analyses reported in this paper pertain to principals with EB-1, EB-2, and EB-3 visas. These highly skilled immigrants are a subset of the main sampled immigrants $(\mathrm{N}=8,573)$ in the Adult Sample (age 18 and older). The response rate for the main sampled immigrants in the Adult Sample was 68.6\%. They will be reinterviewed periodically. 4

Table 2 depicts the sample of highly skilled immigrants. As shown, there are a total of 1,218 principals with EB-1, EB-2, and EB-3 visas (excluding “other workers”). Employment principals were oversampled, because, as shown in Table 2, their representation in the cohort is

4 For succinct overview of the NIS project, see Jasso (2008) and Jasso et al. (2003); for fuller overview, see Jasso et al. (in press). For data or documentation, see the project website (http://nis.princeton.edu ). 
small $-5.4 \%{ }^{5}$

- Table 2 about here -

EB-3 is the more numerous category, followed by EB-2 and then EB-1. Thus, the number follows the ordering from highest skilled to "lowest" skilled. Within EB-1, there is a similar ordering. Multinational executives comprise $63.4 \%$ of the category, followed by outstanding professors and researchers with $21 \%$ and persons of extraordinary ability with $15.7 \%$. In EB-3, however, $55.8 \%$ of the category have baccalaureate degrees, while $44.2 \%$ are skilled workers.

Table 2 also reports the percent adjusting to LPR in the United States. EB-2 has the highest proportion adjustee (86.7\%), followed by EB-3 (67.1\%) and EB-1 (61.4\%). All these categories have a higher proportion adjustee than the entire cohort sample (57.4\%). Thus, new LPRs with the special visas for highly skilled are substantially more likely to already be in the United States at the time they obtain LPR than other new immigrants.

\section{A PORTRAIT OF HIGHLY SKILLED IMMIGRANTS: COMPONENTS OF ETHNICITY}

\subsection{Components of Ethnicity: Country of Birth}

Table 3 (panel A) reports the top five origin countries for the three sets of highly skilled immigrants as well as for the entire NIS-2003 Adult Sample. The three visa categories draw from somewhat different countries. China and India are in the top five for all three groups, with India outranking China throughout, achieving first place in EB-2 and EB-3, and displaying a massive dominance of EB-2 (a full 55\%). EB-1, whose top-five list is the only one with European countries (UK and France), is dominated by UK and Canada, reflecting their dominance among multinational executives. Mexico, which is in top place overall (17.5\%) appears in only one of the three top-five lists (EB-3).

5 In the tables, EB-3 excludes "other workers"; all percentages are based on weighted data, to adjust for sampling stratification. 
- Table 3 about here -

In some sense, EB-2 is the bread-and-butter category for highly skilled immigrants, as it requires an advanced degree or exceptional ability but not quite the luster and the awards of EB-1. It is substantially Asian, with over $80 \%$ from the top four Asian countries and India in the lead. EB-1 is more diverse, with less than half coming from the top five countries. 6,7

\subsection{Components of Ethnicity: Race}

After looking at origin countries in Table 3, it will not be too surprising to see in Table 4 (panel A) that the proportion of immigrants who report themselves as Asian is almost $81 \%$ in EB2 and over $60 \%$ in EB-3. In contrast, EB-1 is almost two-thirds white and only $30 \%$ Asian. Table 4 (panel B) also indicates that EB-2 has less than 3\% immigrants who are of Hispanic origin, while persons of Hispanic origin constitute $9 \%$ of EB-1 and $15 \%$ of EB-3.

- Table 4 about here -

Thus, the racial component of ethnicity shows a strong distinctiveness among highly skilled immigrants. Relative to the cohort, whites are overrepresented in EB-1 and underrepresented in EB-2 and EB-3, substantially so in EB-2. Similarly, Asians are strongly overrepresented in EB-2 and EB-3, especially EB-2, while holding their own in EB-1. Finally, Hispanics are underrepresented in all three categories, and markedly so in EB-2.

\subsection{Components of Ethnicity: Skin Color}

Based on the absence of African countries in Table 3 and of blacks in Table 4 (panel A), as well as the European presence in EB-1 and the Asian dominance of EB-2 and EB-3, we expect

${ }^{6}$ Looking at small states - countries with a population of less than 1.5 million, which may be vulnerable in special ways to losing migrants (Docquier and Schiff 2008) -- the data indicate that while about $2.5 \%$ of immigrants overall come from small states, among highly skilled immigrants, the proportions range from zero in EB-1 to less than three-fourths of one percent in EB-3.

7 If immigrants from all the countries of the former Soviet Union are combined, they constitute $1.61 \%$ of the EB-2 category, slightly ahead of Canada which is in fifth place. Among all immigrants, those from the former Soviet Union constitute $4.77 \%$, slightly ahead of the sixthplace country. 
that all three employment categories are lighter than the cohort overall and that EB-1 is lighter than EB-2 and EB-3. That is exactly what the results indicate (Table 4, panel C).

\subsection{Components of Ethnicity: Language}

Childhood Language Environment. An important element in the early language environment is whether English is an official or dominant language in the country of birth. As expected from the top five origin countries in Table 3 and as shown in Table 5 (panel A), EB-2 and EB-3 immigrants have a large subset born in such countries $-60 \%$ and $58.3 \%$ - higher than EB-1 immigrants $(42.2 \%)$ or the cohort overall (25.4\%).

- Table 5 about here -

The NIS asked respondents about the language(s) they spoke in their home with their parents at age 10. The fraction who spoke English only is highest in EB-1 $-21.2 \%$ - over three times as high as in EB-3 and the cohort overall (6.21\% and 6.99\%, respectively) and almost 13 times higher than in EB-2 (1.64\%). Among these EB-1 English-only immigrants, 84\% were born in United Kingdom and Canada.

Substantial proportions spoke two or more languages at home with their parents at age $10-$ $15.8 \%, 22.4 \%$, and $20.1 \%$ in EB-1, EB-2, and EB-3, respectively, versus $13.2 \%$ in the full cohort.

If one combines the English-only and some-English subsets, the EB-1 immigrants still outdistance their cohortmates - with a total of $29.6 \%$ versus $16.2 \%, 17.5 \%$, and $14 \%$ among EB2, EB-3 and all immigrants, respectively. The leading country in the subset who spoke both English and another language at home at age 10 is India - 37.1\%, 76.2\%, and 38.1\% in EB-1, EB2, and EB-3, respectively - with Philippines a strong second in EB-3 (34.5\%) and South Africa a mild second in EB-1 (11.9\%).

To gain further insight into the language component of ethnicity, we report the top five childhood languages (Table 5, panel A.4), with the caveat that if two or more languages are spoken the top-five list is based on the first language mentioned. English and Mandarin appear in the top-five lists for all three sets of employment immigrants as well as the overall cohort and Spanish in all except EB-2, but their importance differs. While English is at $24.2 \%$ the top 
language for EB-1 immigrants (many of whom are from United Kingdom and Canada), the top language for the cohort overall (whose most numerous contingent is from Mexico) is Spanish with $36.8 \%$. Mandarin is the top language among EB-2 immigrants (18.2\%), while three languages of India (Telugu, Hindi, and Tamil) are in second through fourth place. Among EB-3 immigrants, Tagalog is in first place with 13.6\%; and Tagalog is also in third place among the cohort overall (3.94\%). French appears in second place among EB-1 immigrants (with 72.5\% of these French speakers born in France or Canada); German is in fifth place (3.96\%).

Current Language. By the time they become legal permanent residents of the United States, the language picture is quite different among employment immigrants. As shown in Table 5 (panel B), the proportions who speak only English at home have increased to $37.5 \%$ among EB1 immigrants and $15.2 \%$ and $15.4 \%$ among EB-2 and EB-3 immigrants, respectively - the latter not much different from the cohort as a whole (17.2\%). Of course, combining the English-only and some-English subsets increases the home-English proportions substantially - to $72.8,66.6$, and $62 \%$ in EB-1, EB-2, and EB-3, respectively - contrasted with $48.1 \%$ of the cohort overall.

According to the top-five lists, based on the first-mention language (Table 5, B.3), English is now the top language used at home - with the proportion very high among EB-1 immigrants and declining across the employment categories (53\%, 34.2\%, and 30.9\%, respectively). In the cohort overall, English only reaches second place (26\%), trailing Spanish nontrivially (33.1\%).

As a final look at current language, we report in Table 5 (panel C) the immigrants' choice of interview language. As shown, the proportion choosing to be interviewed in English outstrips the proportion who speak English at home - close to 90\% in EB-1 and EB-2 (87 and 89.4\%, respectively) and 78\% in EB-3. In the cohort overall, however, the proportion interviewed in English is slightly lower (41.2\%) than the total proportion who speak English at home, both exclusively and together with other languages (48.1\%). Respondents who report speaking both English and another language may be heterogeneous in English fluency, with the more fluent choosing English as the interview language. While in the cohort overall, adjustees are more likely to choose English, as would be expected, the opposite obtains in the employment categories. 
Language Shift. A brief initial look at those immigrants whose first-mention language changed from a non-English language to English reveals that the top childhood languages from which the switch was made are French in EB-1, the three Indian languages of Telugu, Hindi, and Tamil in EB-2, Tagalog in EB-3, and Spanish in the cohort overall.

In the subset which was not English-only in childhood but has become English-only, the top languages from which the shift was made are French in EB-1 (33.4\%), Tamil (18.2\%) and Hindi (15\%) in EB-2, Tagalog (11.4\%) in EB-3, and Spanish in the cohort overall (15.8\%); and the top countries are Canada (18.6\%) and India (12\%) in EB-1, India (59.2\%) in EB-2, Philippines (21.9\%) and India (21.9\%) in EB-3, and Philippines (7.8\%) and Mexico (6.62\%) in the cohort overall.

Language is a changeable component of ethnicity. And indeed the cohort as a whole is changing language, with highly skilled immigrants especially more likely to do so.

\subsection{Components of Ethnicity: Religion}

Table 6 reports the top five religious affiliations of the skilled immigrants as well as the whole cohort both during childhood and at the time of the Round 1 interview. The religion categories are: Catholic, Orthodox Christian, Protestant, Muslim, Jew, Buddhist, Hindu, Jain, Sikh, other religion, no religion, and missing. In contrast to language, only a few cases - less than half of $1 \%$ (.49\% in childhood, .27\% currently) - had two or more religions; these are represented by the first religion mentioned.

- Table 6 about here -

Childhood religion. Catholicism was the top religion for the cohort overall as well as for EB-1 and EB-3 principals, but third among EB-2s (Table 6, panel A). Protestantism was second in EB-1, third in EB-3, and fourth in EB-2. Hinduism dominates EB-2 (no surprise, given the dominance of India) and is strong in EB-1 and EB-3 as well, coupled with two other groups, Orthodox Christians (EB-1) and Muslims (EB-2 and EB-3). There is also a nontrivial no-religion contingent - taking third place in EB-1, second place in EB-2, and fourth place in EB-3.

Current religion. The top five religions remain unchanged in EB-3 (Table 6, panel B). 
However, the new top-five lists signal three developments. First, the largest group in EB-1 is the no-religion category $(27.6 \%)$ - increasing by almost ten percentage points from childhood to adulthood. Second, Catholicism is losing adherents in both EB-1 and EB-3 and in the cohort overall. Third, Protestant churches are gaining adherents, in EB-2 and EB-3 and in the whole cohort.

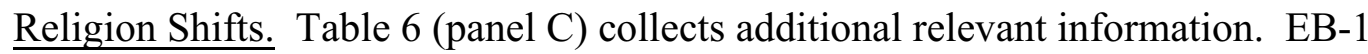
immigrants stand out for their iconoclasm. While the proportion who were raised in a religion is lower than the proportion for the cohort overall $(79.8 \%$ versus $87.5 \%)$, it is not the lowest among the highly skilled immigrants - EB-2 immigrants had the lower proportion of childhood religion at $73.2 \%$. At Round 1, however, EB-1 immigrants have a substantially lower proportion with a religion $-70 \%$ - lower by almost eight percentage points than EB-2 immigrants and lower by 16 percentage points than EB-3 immigrants.

Comparing the religious affiliation of individual immigrants in childhood and at the time of the Round 1 interview (Table 6, C.3), EB-1 again stands out with the lowest proportion who are in the same category at both time points (where the categories include not only religions but also the no-religion category and missing) - $80.3 \%$ versus $89 \%$ among the other highly skilled immigrants and $88.3 \%$ in the cohort overall.

A different way of looking at religious shifts is to assess the fraction of no-religion children who report a religion in adulthood and vice-versa. Looking at the shift from no-religion to religion, the highly skilled immigrants differ only slightly among themselves - with proportions in the $20-23 \%$ range - and are similar to the cohort overall, in which $21.2 \%$ of the no-religion children have a religion at the Round 1 interview. However, among respondents who had a religion in childhood, only small proportions abandoned all religion, except for EB-1 immigrants; in this set $16.8 \%$ changed from a religion to no religion. Among religion-leavers, the top childhood religions are Protestant (35\%) and Catholic (29\%), and the top origin country is UK $(31 \%)$

These results suggest that the religion component of ethnicity is less malleable than the 
language component. For example, while English use has become widespread, the largest proportion with a different religion - in EB-1 - does not quite reach $20 \%$, and is only in the 11 $12 \%$ range in EB-2, EB-3, and the cohort overall. Of course, it may be that some fraction of those retaining their religion are worshiping now in an American form, as suggested by data (not shown) for U.S. co-worshipers and English use in religious services.

$$
* * *
$$

The foregoing description of ethnicity in a cohort of new legal immigrants, made possible by new data, suggests two propositions: First, the ethnicity portfolio of immigrants contains more languages than religions. Second, religion is more persistent than language (possibly because religions tend to be linguistically flexible). Thus, in the process of incorporation (or globalization), language is shed before religion; and religion may not be shed at all, except among ultra highly skilled immigrants.

\section{OTHER CHARACTERISTICS OF HIGHLY SKILLED IMMIGRANTS}

As with the components of ethnicity, this paper reports for the first time a set of selected characteristics of highly skilled immigrants. This information has never before been available and has been the subject of much speculation among researchers and policymakers.

\subsection{Gender and Age}

As shown in Table 7 (panel A), women are underrepresented among highly skilled principals, reaching no higher than $38 \%$ in EB-3 versus $57 \%$ in the overall cohort. Moreover, in EB-1 and EB-2 (the more highly skilled of the three categories), women register less than a fifth of the category -18.4 and $17.4 \%$ in EB-1 and EB-2, respectively.

- Table 7 about here -

Age at admission to LPR is lower than the average in EB-2 and EB-3 - hovering near 35 years on average - but 7 years higher in EB-1, reflecting the years it takes to accumulate the record necessary for an EB-1 visa..

\subsection{Educational Attainment}


As expected, educational attainment is higher on average among highly skilled immigrants than in the cohort overall (Table 7, panel B). EB-3, which has the lowest requirements, has average schooling of almost 15 years -- three years higher than the cohort overall. EB-1 and EB-2 have average schooling above 17 years. Within EB-1, average schooling, as would be expected, is highest among the subset of outstanding professors and researchers and lowest among multinational executives (the averages are 18,20, and 16 years for the extraordinary ability subset, outstanding professors, and executives, respectively). Within EB-3, again as would be expected, average schooling is 16 years among the set with bachelor's degrees and 13 years among skilled workers (13 years is the figure used by Docquier and Schiff (2008) to demarcate highly skilled migrants).

Recall that EB-2 has the highest proportion adjustee -- almost 87\% (Table 2). Thus, it is not surprising that EB-2 has the highest rate of U.S. schooling - almost half of the EB-2 principals obtained some of their education in the United States, versus 24 and 23\%, respectively, for EB-1 and EB-3 (and 19\% of the cohort overall). Among those who obtained some schooling in the U.S., the amount is very similar across all three EB categories - about 3.5-4 years - less than the 4.46 years among the cohort overall (suggesting a future direction to explore, namely, schooling venue among the immigrants who become spouses of U.S. citizens). Moreover, schooling may not yet be completed, and hence patterns may shift over time.

A doctorate degree is an important measure of skill. The proportion with a $\mathrm{PhD}$ is highest in EB-1 (26\%), moderate in EB-2 (14.6\%), and low both in EB-3 and in the cohort overall (a little more than one percent). Within EB-1, $42.6 \%$ of the extraordinary ability subset and $83.2 \%$ of professors have $\mathrm{PhDs}$, while only $3.49 \%$ of multinational executives do so.

Some of the PhDs were earned in the United States - about 10-11\% of the PhDs in EB-1 and EB-2. Within EB-1, U.S. doctorates are about $23 \%$ of the doctorates in the extraordinaryability subset and $28 \%$ in the professors subset.

Again, the proportion with a $\mathrm{PhD}$ and the proportion obtaining it in the United States may 
increase with time in the U.S. after LPR. ${ }^{8}$

\subsection{Visa History and Visa Process}

Duration of visa process. The visa process was considerably shorter in EB-1 than in EB-2 and EB-3 - 2.66 years versus 3.56 in EB-2 and 3.95 in EB-3 - as would be expected given that EB-1 does not require labor certification. Moreover, all the employment cases have a shorter visa process than the cohort overall (4.44 years).

Previous illegal experience. There are three indicators of previous illegal experience in the official immigrant record of employment immigrants (Jasso et al., 2008). All pertain to adjustees, and all are based on the nonimmigrant code. The first is having the code EWI, which indicates entry without inspection (the euphemism for surreptitious entry). The second is having the code UU, which indicates unknown. The third is having no information at all in the nonimmigrant code field. The most conservative measure counts only EWI cases, and the most encompassing measure counts as well the UU and missing codes. Table 7 (panel C) reports the range from the EWI-only measure to the measure that incorporates all three indicators.

As shown, both the low and the high end of the range increase from EB-1 to EB-2 to EB-3 and are higher in the cohort overall. Within EB-1, which has zero as the lower bound, the higher end of the range registers $7.18 \%$ for the extraordinary-ability subset, $2.41 \%$ for the professors, and $4.28 \%$ for the executives. Within EB-3, the skilled subset has a range of $8.98 \%$ to $36 \%$ and the college graduates from zero to $6.14 \%$. These results suggest that in a world of restricted immigration and lengthy visa processing, no one is immune from lapsing into illegality, not even highly skilled immigrants. Moreover, these figures underestimate true previous illegal experience, which may also include spells of visa overstay and unauthorized employment (Jasso et al. 2008).

8 Legislation introduced in the U.S. Congress in 2008 would provide numerically unlimited visas to persons who obtain a U.S. PhD. If such legislation were enacted, it would increase the average schooling of employment immigrants and reduce that of spouse-of-U.S.citizen immigrants, as discussed by Jasso, Rosenzweig, and Smith (2000). 
Nonimmigrant-immigrant trajectories. As seen in Table $2,70 \%$ of the highly skilled principals are already in the United States and adjusting their status to LPR. It is thus of interest to examine the nonimmigrant origins of employment principals. As reported in Wadhwa et al. (2007), the largest nonimmigrant category for EB-1 consists of L1 intracompany transferees (48.9\%), followed by H-1B (28\%), and the largest nonimmigrant visa category for EB-2 and EB-3 is $\mathrm{H}-1 \mathrm{~B}(89 \%$ and $49.5 \%$, respectively). Moreover, the previous illegal experience of the EB-3 set, in particular, is of some interest, as discussed above.

An important feature of immigration to the United States is that many skilled immigrants acquire legal permanent residence with visas other than employment visas. As shown in Wadhwa et al. (2007), employment visas are the dominant pathway to LPR for the subset adjusting from H$1 \mathrm{~B}$ visas, a total of over $69 \%$. However, the dominant pathway to LPR for those adjusting from F1 or who were ever student visa holders is the spouse-of-US-citizen visa, with $79 \%$ of the F1 adjustees and $59 \%$ of those who were ever F1s using this visa. These figures suggest that international students are attractive marriage prospects and thus have a numerically unlimited avenue for remaining in the United States besides the numerically-limited employment visas. As noted above, if proposed legislation is enacted, the marriage visa would no longer be the only numerically-unlimited route to immigration for someone with a U.S. PhD.

\subsection{Monetary Transfers}

An important question concerns transfers, both to and from immigrants, and their patterns and determinants. Recent literature highlights the possibility that highly skilled immigrants remit less than the less skilled (Niimi, Ozden, and Schiff 2008). A preliminary look at NIS data indicates that the proportion of adult immigrants involved in transfers, as well as sending remittances, is higher among highly skilled immigrants in EB-2 and EB-3 than in the cohort overall, with mixed results for EB-1 (Table 7, panel D). Of course, future research should examine remittance amounts and look as well at highly skilled immigrants with family or other 
types of visas. 9

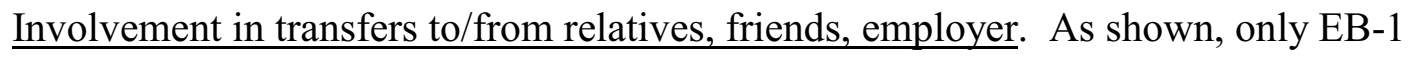

immigrants have a lower proportion involved in transfers than the cohort overall. It is interesting, however, that the proportion engaged in transfers increases from EB-1 to EB-2 to EB-3, providing a "local" example of the Niimi, Ozden, and Schiff (2008) hypothesis.

Transfers between spouses. Larger proportions of the highly skilled principals sent money to their spouses when living apart than in the cohort overall $-43.1 \%$ and $39 \%$ among EB-2 and EB-3 men, respectively, versus 31.8\%. In within-couple transfers, immigrant men are both more likely to send money and, in EB-3 and the full cohort, less likely to receive it than immigrant women, with the gender differential especially large in the cohort overall (hence, among immigrants with non-EB visas).

Transfers to/from own and spouse's parents. Remittances to parents are substantially more likely among EB-2 and EB-3 immigrants than in the cohort overall - for example, to own parents, $23.1 \%$ and $22.5 \%$ among EB-2 and EB-3 men, respectively, versus $10.7 \%$. Remittances are also about twice as likely to own parents as to spouse's parents. Finally, the proportions sending money to parents are markedly larger than the proportions receiving money.

\subsection{Social Integration}

Dietary change. The dietary change measure indicates a progression in the direction of greater dietary change from EB-1 to EB-2 to EB-3 to the overall cohort (Table 7, panel E). This suggests that the most advantaged immigrants already eat their preferred foods and have access to

9 Estimates in this section are based on information obtained from both the main sampled immigrant and the spouse, if the main respondent designated the spouse as the financially knowledgeable person. Estimates of involvement in transfers are based on a randomized 20\% subset of the cohort; estimates of within-couple transfers are based on a randomized $80 \%$ subset of the cohort, for whom information on living apart was obtained; estimates of transfers to parents are based on the same $80 \%$ subset of the cohort, and, to ensure comparability of the two spouses' information, exclude couples living apart. All results are robust to changes in sample definition. Estimates of within-couple and parent transfers exclude tiny fractions involved in bidirectional transfers; the largest such excluded figure is $1.93 \%$ in within-couple transfers in the entire cohort. 
them wherever they are, whereas the less advantaged find new foods that they may prefer.

Intention to stay. The same forces which brought EB-1 and EB-2 immigrants to the United States may propel them elsewhere. The proportions indicating that they intend to stay in the United States are 58.6 and 52.4\%, respectively, substantially lower than the cohort overall $78.3 \%$. EB-3 also shows a moderately lower intention to stay than the cohort overall (70.6\%). Thus, employment principals appear to see opportunities beyond the United States. Of course, the longitudinal nature of the NIS will make it possible to assess the actual emigration of highly skilled immigrants.

Little measures of assimilation. Beyond the large indicators of assimilation, there are many little indicators, which NIS data provide an opportunity to observe. These include adopting American monetary currency and American ways of measuring length, weight, temperature, etc.

As an initial look at these little measures of assimilation, we examine the use of dollars for reporting the estimated earnings in seven occupations in the country of last residence (CLR). Because respondents were asked to provide estimates in the CLR's own currency, the probability of using dollars may not be high, but respondents who do use dollars are manifesting a strong inclination to "think in dollars". Table 7 ( panel E) reports the proportion of CLR estimates provided in dollars. As shown, highly skilled immigrants are more likely to use dollars than the cohort overall $-37.2 \%$ in EB-1 and $33.2 \%$ in EB-3, versus $28.9 \%$ in the cohort (no figure is reported for EB-2 because of small sample size).

\section{CONCLUDING NOTE}

This paper has reported information never before available about highly skilled immigrants to the United States, including a close look at the classic components of ethnicity and selected other characteristics. The stage is now set for exploration of the determinants of shifts in language and religion, as well as the effects of the five components of ethnicity on a wide range of experiences and behaviors, including aspects of the visa process and indicators of assimilation and what may be called the Globalista impulse. 
After aerial reconnaissance, it is time to go under the ledges and into the caves. 


\section{REFERENCES}

Constant, A., and Zimmermann, K. F. (2008) "Measuring ethnic identity and its impact on economic behavior." Journal of the European Economic Association Vol. 6 Nos. 2-3, pp. 424-433.

Docquier, F., and Schiff, M. (2008) "Measuring skilled emigration rates: the case of small states.” IZA Discussion Paper \# 3388.

Jasso, G. (2008) “New immigrant survey,” Darity, W. A. (Ed.), International Encyclopedia of the Social Sciences, 2nd Ed., Vol. 5, Detroit, Macmillan Reference USA, pp. 499-500.

Jasso, G., Massey, D. S., Rosenzweig, M. R., and Smith, J. P. (2003) "The new immigrant survey in the U.S.: the experience over time." www.migrationinformation.org .

Jasso, G., Massey, D. S., Rosenzweig, M. R., and Smith, J. P. (2008) “From illegal to legal: estimating previous illegal experience among new legal immigrants to the United States," International Migration Review, Vol. 42 No. 4, pp. 803-843.

Jasso, G., Massey, D. S., Rosenzweig, M. R., and Smith, J. P. (In press) “The U.S. New Immigrant Survey: overview and preliminary results based on the new-immigrant cohorts of 1996 and 2003,” Morgan, B. and Nicholson, B. (Eds.), Immigration Research and Statistics Service Workshop on Longitudinal Surveys and Cross-Cultural Survey Design: Workshop Proceedings, London, UK, Crown Publishing, pp. 29-46.

Jasso, G., M. R. Rosenzweig, and J. P. Smith. (2000) "The changing skill of new immigrants to the United States: recent trends and their determinants," Borjas, G. J. (Ed.), Issues in the Economics of Immigration, Chicago, IL: University of Chicago Press, pp. 185-225.

Niimi, Yoko, Caglar Ozden, and Maurice Schiff. 2008. "Remittances and the brain drain: skilled migrants do remit less.” IZA Discussion Paper No. 3393.

Wadhwa, V., Jasso, G., Rissing, B., Gereffi, G., and Freeman, R. B. (2007) Intellectual Property, the Immigration Backlog, and a Reverse Brain-Drain: America's New Immigrant Entrepreneurs, Part III (August 22, 2007). Available at SSRN: http://ssrn.com/abstract $=1008366$. 
Table 1. Categories and Subcategories for Highly Skilled Principals in the First Three Employment Preference Categories (EB-1, EB-2, and EB-3) in 2003

\begin{tabular}{ccc}
\hline \hline \multicolumn{2}{c}{ Visa Codes } \\
Arrival & Adjustee & Description \\
A. Employment First Preference (EB-1) - Priority Workers \\
E11 & E16 & Aliens with extraordinary ability \\
E12 & E17 & Outstanding professors or researchers \\
E13 & E18 & Multinational executives or managers \\
\hline & & B. Employment Second Preference (EB-2) \\
E21 & E26 & $\begin{array}{c}\text { Professionals with advanced degrees } \\
\text { or aliens of exceptional ability }\end{array}$ \\
\hline & & C. Employment Third Preference (EB-3) \\
E31 & E36 & Skilled workers \\
E32 & E37 & Professionals with baccalaureate degrees \\
\hline
\end{tabular}

Notes: The third preference category includes a subcategory of less-skilled "other workers," which is excluded here. Each category also provides visas for the spouses and minor children of the principals; those visas have distinct codes. 
Table 2. EB-1, EB-2, and EB-3 Immigrant Principals in the NIS-2003 Adult Sample

\begin{tabular}{lccc}
\hline \multicolumn{1}{c}{ Visa } & Percent of Sample & Percent Adjustee & $\boldsymbol{N}$ \\
\hline EB-1 Principal & 0.86 & 61.4 & 195 \\
Extraordinary ability & 0.14 & 59.5 & 31 \\
Professors/researchers & 0.18 & 81.2 & 40 \\
Multinational executives & 0.55 & 55.3 & 124 \\
EB-2 Principal & 1.14 & 86.7 & 258 \\
EB-3 Principal & 3.34 & 67.1 & 765 \\
Skilled workers & 1.48 & 71.8 & 338 \\
Baccalaureate & 1.87 & 63.5 & 427 \\
All EB-1, EB-2, EB-3 Principals & 5.34 & 70.4 & 1,218 \\
All Immigrants & 100 & 57.4 & 8,573 \\
\hline
\end{tabular}

Notes: Employment principals were oversampled in NIS-2003. Percentages are based on weighted data, to adjust for sample stratification. The EB-3 category excludes the less-skilled "other workers". 
Table 3. Components of Ethnicity: Top Five Countries of Birth, by Employment Visa Category, NIS-2003 Cohort

\begin{tabular}{cccc}
\hline \hline & Employment Visa Principals & & All Immigrants \\
EB-1 & EB-2 & EB-3 & Mexico \\
\hline United Kingdom & India & India & 17.5 \\
13.4 & 55.0 & 23.4 & India \\
Canada & China & Philippines & 7.30 \\
11.3 & 19.9 & 22.1 & El Salvador \\
India & Taiwan & Mexico & 6.11 \\
10.2 & 3.53 & 6.10 & Philippines \\
China & Korea & China & 5.47 \\
8.80 & 3.28 & 5.47 & China \\
France & Canada & Korea & 5.27 \\
5.34 & 1.50 & 4.05 & Top Five \\
Top Five & Top Five & Top Five & 41.7 \\
49.0 & 83.2 & 61.2 & \\
\hline
\end{tabular}


Table 4. Components of Ethnicity: Race, Hispanic Origin, and Skin Color, by Employment Visa Category, NIS-2003 Cohort

\begin{tabular}{|c|c|c|c|c|}
\hline \multirow{2}{*}{ Characteristic } & \multicolumn{3}{|c|}{ Employment Visa Principals } & \multirow{2}{*}{$\underset{\text { Immigrants }}{\text { All }}$} \\
\hline & EB-1 & EB-2 & EB-3 & \\
\hline \multicolumn{5}{|c|}{ A. Race and Hispanic Origin } \\
\hline White & 63.2 & 14.8 & 29.3 & 48.1 \\
\hline White, Hispanic & 6.92 & --- & 10.1 & 28.5 \\
\hline White, not Hispanic & 56.3 & 12.8 & 19.1 & 19.5 \\
\hline Black & --- & --- & --- & 11.2 \\
\hline American Indian & --- & --- & --- & 2.51 \\
\hline Asian & 30.2 & 80.7 & 61.5 & 28.6 \\
\hline Asian, not Hispanic & 29.0 & 80.7 & 59.9 & 28.2 \\
\hline Pacific & --- & --- & --- & 0.77 \\
\hline Two or more races & --- & --- & --- & 1.15 \\
\hline No information on race & --- & --- & 4.13 & 7.60 \\
\hline No information on race, Hispanic & --- & --- & 2.05 & 5.63 \\
\hline \multicolumn{5}{|c|}{ B. Hispanic Origin } \\
\hline Hispanic origin & 9.17 & --- & 15.2 & 38.1 \\
\hline Not Hispanic origin & 89.8 & 97.2 & 84.2 & 61.3 \\
\hline No information on Hispanic origin & --- & --- & --- & .56 \\
\hline \multicolumn{5}{|c|}{ C. Skin Color } \\
\hline $\begin{array}{l}\text { Assessed by interviewer (11-point } \\
\text { scale) }\end{array}$ & 2.56 & 3.80 & 3.56 & 4.18 \\
\hline
\end{tabular}

Note: Cells with fewer than 14 observations left blank. 
Table 5. Components of Ethnicity: Home Language, During Childhood and Currently, by Employment Visa Category, NIS-2003 Cohort

\section{Employment Visa Principals}

EB-1

EB-2

EB-3

All Immigrants

A. Exposure to English and Home Languages During Childhood

A.1. English Is An Official or Dominant Language of the Country of Birth
42.2
60.0
58.3
25.4

A.2. Spoke Only English at Home with Parents at Age 10
21.2
1.64
6.21
6.99

A.3. Spoke English (Only or with Another Language) at Home with Parents at Age 10
29.6
16.2
17.5
14.0

A.4. Top Five Languages Spoken at Home with Parents at Age 10

$\begin{array}{cccc}\text { English } & \text { Mandarin } & \text { Tagalog } & \text { Spanish } \\ 24.2 & 18.2 & 13.6 & 36.8 \\ \text { French } & \text { Telugu } & \text { Spanish } & \text { English } \\ 13.5 & 15.8 & 11.9 & 8.06 \\ \text { Mandarin } & \text { Hindi } & \text { English } & \text { Tagalog } \\ 8.79 & 9.91 & 8.35 & 3.94 \\ \text { Spanish } & \text { Tamil } & \text { Mandarin } & \text { Mandarin } \\ 8.46 & 7.26 & 5.29 & 3.61 \\ \text { German } & \text { English } & \text { Hindi } & \text { Russian } \\ 3.96 & 4.61 & 4.33 & 3.46\end{array}$

\section{B. Home Languages at Round 1 Interview}

B.1. Speaks Only English at Home at Round 1 Interview
37.5
15.2
15.4
17.2

B.2. Speaks English (Only or with Another Language) at Home at Round 1 Interview
72.8
66.6
62.0
48.1

B.3. Top Five Home Languages at Round 1 Interview

$\begin{array}{cccc}\text { English } & \text { English } & \text { English } & \text { Spanish } \\ 53.0 & 34.2 & 30.9 & 33.1 \\ \text { Mandarin } & \text { Mandarin } & \text { Spanish } & \text { English } \\ 9.84 & 17.3 & 10.7 & 26.0 \\ \text { Spanish } & & \text { Tagalog } & \text { Mandarin } \\ 6.98 & \text { Telugu } & 8.38 & 3.26 \\ \text { French } & 11.3 & \text { Mandarin } & \text { Tagalog } \\ 2.92 & \text { Hindi } & 5.07 & 2.87 \\ \text { Russian } & 7.00 & \text { Korean } & \text { Russian } \\ 2.73 & \text { Tamil } & 3.81 & 2.87\end{array}$




\section{Interviewed in English at Round 1 \\ C.1. New Arrivals}

88.7

94.2

83.5

37.1

\section{C.2. Adjustees}

86.0

88.7

75.3

44.2

\section{C.3. All Immigrants}

87.0

89.4

78.0

41.2

Note: Among respondents reporting more than one language spoken at home at age 10 or at the time of the Round 1 interview, percentages in the top-five lists are based on the first language mentioned. 
Table 6. Components of Ethnicity: Religion During Childhood and Currently, by Employment Visa Category, NIS-2003 Cohort

\begin{tabular}{|c|c|c|c|}
\hline \multicolumn{3}{|c|}{ Employment Visa Principals } & \multirow{2}{*}{ All Immigrants } \\
\hline EB-1 & EB-2 & EB-3 & \\
\hline \multicolumn{4}{|c|}{ A. Top Five Religions During Childhood } \\
\hline $\begin{array}{l}\text { Catholic } \\
28.3\end{array}$ & $\begin{array}{l}\text { Hindu } \\
46.6\end{array}$ & $\begin{array}{l}\text { Catholic } \\
41.8\end{array}$ & $\begin{array}{l}\text { Catholic } \\
46.2\end{array}$ \\
\hline $\begin{array}{l}\text { Protestant } \\
22.1\end{array}$ & $\begin{array}{c}\text { No Religion } \\
23.2\end{array}$ & $\begin{array}{l}\text { Hindu } \\
18.2\end{array}$ & $\begin{array}{l}\text { Protestant } \\
13.1\end{array}$ \\
\hline $\begin{array}{c}\text { No Religion } \\
17.9\end{array}$ & $\begin{array}{c}\text { Catholic } \\
8.44\end{array}$ & $\begin{array}{l}\text { Protestant } \\
12.8\end{array}$ & $\begin{array}{c}\text { No Religion } \\
10.9\end{array}$ \\
\hline $\begin{array}{l}\text { Hindu } \\
9.92\end{array}$ & $\begin{array}{l}\text { Protestant } \\
\quad 6.75\end{array}$ & $\begin{array}{c}\text { No Religion } \\
11.3\end{array}$ & $\begin{array}{c}\text { Orthodox Christian } \\
8.21\end{array}$ \\
\hline $\begin{array}{c}\text { Orthodox Christian } \\
7.49\end{array}$ & $\begin{array}{l}\text { Muslim } \\
3.57\end{array}$ & $\begin{array}{l}\text { Muslim } \\
4.89\end{array}$ & $\begin{array}{l}\text { Muslim } \\
7.19\end{array}$ \\
\hline \multicolumn{4}{|c|}{ B. Top Five Religions at Round 1 Interview } \\
\hline $\begin{array}{c}\text { No Religion } \\
27.6\end{array}$ & $\begin{array}{l}\text { Hindu } \\
45.7\end{array}$ & $\begin{array}{l}\text { Catholic } \\
37.6\end{array}$ & $\begin{array}{l}\text { Catholic } \\
41.3\end{array}$ \\
\hline $\begin{array}{c}\text { Catholic } \\
24.7\end{array}$ & $\begin{array}{c}\text { No Religion } \\
19.4\end{array}$ & $\begin{array}{l}\text { Hindu } \\
17.8\end{array}$ & $\begin{array}{l}\text { Protestant } \\
\quad 16.6\end{array}$ \\
\hline $\begin{array}{l}\text { Protestant } \\
18.1\end{array}$ & $\begin{array}{l}\text { Protestant } \\
11.8\end{array}$ & $\begin{array}{l}\text { Protestant } \\
16.4\end{array}$ & $\begin{array}{c}\text { No Religion } \\
12.4\end{array}$ \\
\hline $\begin{array}{c}\text { Orthodox Christian } \\
8.99\end{array}$ & $\begin{array}{c}\text { Catholic } \\
8.90\end{array}$ & $\begin{array}{c}\text { No Religion } \\
12.4\end{array}$ & $\begin{array}{c}\text { Orthodox Christian } \\
8.71\end{array}$ \\
\hline $\begin{array}{l}\text { Hindu } \\
8.89\end{array}$ & $\begin{array}{c}\text { Orthodox Christian } \\
4.92\end{array}$ & $\underset{4.73}{\text { Muslim }}$ & $\begin{array}{l}\text { Muslim } \\
6.96\end{array}$ \\
\hline
\end{tabular}

\section{Shifts in Religion}

\section{C.1. Had Religion as a Child}
79.8
73.2
87.6
87.5

\section{C.2. Has Religion at Round 1 Interview}

70.0

$$
77.9
$$

86.6

86.4

C.3. Religion at Round 1 Interview the Same as in Childhood
80.3
89.2
89.0
88.3

\section{C.4. Among No-Religion Children, Has Religion at Round 1 Interview}

$\begin{array}{llll}20.4 & 23.0 & 22.0 & 21.2\end{array}$

\section{C.5. Among Those with Childhood Religion, Has No Religion at Round 1 Interview}
16.8
2.01
3.95
4.15 
Table 7. Basic Characteristics of Highly Skilled Immigrants: NIS-2003

\begin{tabular}{|c|c|c|c|c|}
\hline \multirow{2}{*}{ Characteristic } & \multicolumn{3}{|c|}{ Employment Visa Principals } & \multirow{2}{*}{$\begin{array}{l}\text { All } \\
\text { Immigrants }\end{array}$} \\
\hline & EB-1 & EB-2 & EB-3 & \\
\hline \multicolumn{5}{|l|}{ A. Gender and Age } \\
\hline Percent female & 18.4 & 17.4 & 38.4 & 56.5 \\
\hline Age at admission to LPR (years) & 42.0 & 35.1 & 35.6 & 38.9 \\
\hline \multicolumn{5}{|c|}{ B. Educational Attainment and History } \\
\hline Average schooling (years) & 17.2 & 17.5 & 14.7 & 11.9 \\
\hline Any schooling in U.S. & 23.9 & 49.4 & 22.7 & 19.2 \\
\hline Years schooling in U.S. (if $>0$ ) & 3.71 & 3.76 & 3.56 & 4.46 \\
\hline Have $\mathrm{PhD}$ & 26.3 & 14.6 & 1.12 & 1.24 \\
\hline Have PhD earned in U.S. & 9.5 & 10.9 & 0.49 & 0.68 \\
\hline \multicolumn{5}{|l|}{ C. Visa History and Visa Process } \\
\hline Duration of visa process (years) & 2.66 & 3.56 & 3.95 & 4.44 \\
\hline Previous illegal experience & $0-4.34$ & $.37-7.24$ & $3.97-19.3$ & $11.4-30.7$ \\
\hline \multicolumn{5}{|c|}{$\begin{array}{l}\text { D. Transfers within the Previous Twelve Months To/From Persons Not Living in the } \\
\text { Same House (Figures in Parentheses Are for Men Only) }\end{array}$} \\
\hline $\begin{array}{l}\text { Involved in transfers with } \\
\text { relatives, friends, employer }\end{array}$ & $9.23(10.5)$ & $17.7(18.1)$ & $23.2(21.0)$ & $13.1(13.9)$ \\
\hline Lived apart from spouse & $10.8(8.60)$ & $13.4(13.6)$ & $16.7(15.1)$ & $16.4(14.5)$ \\
\hline Transfers to spouse & --- & $39.5(43.1)$ & $33.5(39.0)$ & $15.0(31.8)$ \\
\hline Transfers from spouse & --- & 0 & $8.15(0)$ & $24.3(7.11)$ \\
\hline Transfers to own parents & $9.79(10.1)$ & $20.8(23.1)$ & $23.1(22.5)$ & $8.64(10.7)$ \\
\hline Transfers from own parents & $0.66(.79)$ & $1.12(0)$ & $3.23(1.85)$ & $4.32(4.71)$ \\
\hline Transfers to spouse's parents & $5.29(5.48)$ & $9.34(10.0)$ & $9.80(8.55)$ & $4.51(5.48)$ \\
\hline Transfers from spouse's parents & $2.37(2.85)$ & 0 & $1.29(1.18)$ & $1.21(1.22)$ \\
\hline \multicolumn{5}{|l|}{ E. Social Integration } \\
\hline Dietary change (10-point scale) & 4.15 & 4.71 & 4.96 & 5.38 \\
\hline Intend to stay in U.S. & 58.6 & 52.4 & 70.6 & 78.3 \\
\hline $\begin{array}{l}\text { Use dollars to report estimated } \\
\text { earnings in occupations in CLR }\end{array}$ & 37.2 & --- & 33.2 & 28.9 \\
\hline
\end{tabular}

Note: Cells left blank for subsets with fewer than 15 observations. 